\title{
RESEARCH
}

Open Access

\section{Complete genome sequences of Aeromonas and Pseudomonas phages as a supportive tool for development of antibacterial treatment in aquaculture}

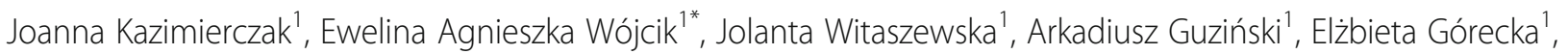
Małgorzata Stańczyk ${ }^{1}$, Edyta Kaczorek², Andrzej Krzysztof Siwicki ${ }^{2}$ and Jarosław Dastych ${ }^{1}$

\begin{abstract}
Background: Aquaculture is the fastest growing sector of food production worldwide. However, one of the major reasons limiting its effectiveness are infectious diseases among aquatic organisms resulting in vast economic losses. Fighting such infections with chemotherapy is normally used as a rapid and effective treatment. The rise of antibiotic resistance, however, is limiting the efficacy of antibiotics and creates environmental and human safety concerns due to their massive application in the aquatic environment. Bacteriophages are an alternative solution that could be considered in order to protect fish against pathogens while minimizing the side-effects for the environment and humans. Bacteriophages kill bacteria via different mechanisms than antibiotics, and so fit nicely into the 'novel mode of action' concept desired for all new antibacterial agents.
\end{abstract}

Methods: The bacteriophages were isolated from sewage water and characterized by RFLP, spectrum of specificity, transmission electron microscopy (TEM) and sequencing (WGS). Bioinformatics analysis of genomic data enables an in-depth characterization of phages and the choice of phages. This allows an optimised choice of phage for therapy, excluding those with toxin genes, virulence factor genes, and genes responsible for lysogeny.

Results: In this study, we isolated eleven new bacteriophages: seven infecting Aeromonas and four infecting Pseudomonas, which significantly increases the genomic information of Aeromonas and Pseudomonas phages. Bioinformatics analysis of genomic data, assessing the likelihood of these phages to enter the lysogenic cycle with experimental data on their specificity towards large number of bacterial field isolates representing different locations.

Conclusions: From 11 newly isolated bacteriophages only 6 (25AhydR2PP, 50AhydR13PP, 60AhydR15PP, 22PfluR64PP, 67PfluR64PP, 71PfluR64PP) have a potential to be used in phage therapy due to confirmed lytic lifestyle and absence of virulence or resistance genes.

Keywords: Bacteriophages, WGS, Aeromonas hydrophila, Pseudomonas fluorescens, Aquaculture

\footnotetext{
* Correspondence: ewojcik@proteonpharma.com

'Proteon Pharmaceuticals, Lodz, Poland

Full list of author information is available at the end of the article
}

(c) The Author(s). 2019 Open Access This article is distributed under the terms of the Creative Commons Attribution 4.0 International License (http://creativecommons.org/licenses/by/4.0/), which permits unrestricted use, distribution, and reproduction in any medium, provided you give appropriate credit to the original author(s) and the source, provide a link to the Creative Commons license, and indicate if changes were made. The Creative Commons Public Domain Dedication waiver (http://creativecommons.org/publicdomain/zero/1.0/) applies to the data made available in this article, unless otherwise stated. 


\section{Background}

Aeromonas and Pseudomonas are considered one of the most important fish pathogens among the etiological agents of bacterial fish diseases with capacity of hemolysis and biofilm formation [1-3]. These aquatic bacteria are responsible for ulcer type diseases including ulcerative syndrome, bacteria haemorrhagic septicaemia, tail and fin rot, bacteria gill rot and dropsy [4-10]. The increasing prevalence of bacterial infections leads to the indiscriminate use of antimicrobials that are the most common solution in combating pathogenic microorganisms. However, in the case of aquaculture, the range of authorized antibiotics is very narrow, e.g. the Food and Drug Administration (FDA) in 2014 approved only oxytetracycline, florfenicol, and sulfadimethoxine/ormetoprim [4]. In addition, the vast majority of bacteria pathogenic to aquaculture are resistant to multiple antibiotics $[11,12]$. That forces fish farmers to look for alternative solutions that allow effective protection of breeding populations. Bacteriophages (phages) are one alternative solution that could be considered as a prospective anti-microbial strategy in aquaculture [1, 1324]. Bacteriophages are the most abundant biological entities on Earth. In almost all ecosystems that so far have been subjected to in-depth studies, it has been estimated that there are around ten phages for every microbial cell giving approximately $10^{30}-10^{31}$ phages globally [25, 26]. However, their genomic sequences represent a small fraction in public databases. Only 1956 bacteriophage genomes are currently available in the NCBI genome database [National Center for Biotechnology Information (NCBI) Genome database https://www.ncbi.nlm.nih.gov/genome. Accessed 27 Nov 2018], of which 19 are genome sequences of phages infecting Aeromonas (phages belonging to Myoviridae, Podoviridae, and Siphoviridae families) and 144 infecting Pseudomonas (phages belonging to Myoviridae, Podoviridae, Siphoviridae, Cystoviridae, Leviviridae, Inoviridae families and 5 unclassified). Phages useful for therapeutic purposes must meet numerous criteria, from which the most important is their lytic nature. Only whole genome sequencing (WGS) enable an in-depth characterization of phages and the choice of the phages suitable for phage therapy. In this study, we present 7 new phages infecting Aeromonas and 4 new phages infecting Pseudomonas that significantly increase the genomic information of Aeromonas and Pseudomonas phages. Furthermore, we present results of bioinformatics analysis of genomic data assessing the likelihood of these phages to enter the lysogenic cycle and experimental data on their specificity towards a large number of bacterial field isolates representing different location. Taken together these data provide an essential basis for rational selection of bacteriophages for application in phage therapy of affected populations.

\section{Methods \\ Bacterial strains isolation}

Bacterial strains were isolated from diseased rainbow trout (Oncorhynchus mykiss, Walbaum 1972) from 12 different freshwater farms in Poland. Samples were collected from March 2013 to August 2014 and at least 10 fish from each farm were examined. For further research samples of damaged tissues (spleen, kidney, gills) were taken. Prepared samples were diluted with sterile phosphate-buffered saline (PBS) at 1:1 $(w / v)$. The suspensions were incubated at $27^{\circ} \mathrm{C}$ for $48 \mathrm{~h}$ on Aeromonas selective medium (AM) (Oxoid, Basingstoke, UK) and King B Agar (Biolab, Polska). The presumed Aeromonas and Pseudomonas colonies were isolated and identified by Gram-stain, oxidase and catalase tests, standard biochemical characteristics using the API 20NE system (bio Merieux, France) and genetically by restriction fragment length polymorphism analysis (RFLP) of the $16 \mathrm{~S}$ rRNA gene for Aeromonas spp. [27] and by species-specific PCR with DNA primers against a sequence of the $16 \mathrm{~S}$ rRNA gene for $P$. fluorescens described by Scarpellini et al. [28].

Forty five strains were isolated during this study and 13 were provided by the Adam Mickiewicz University in Poznan as reference strains (both available in public repositories and clinical human isolates, Table 1.). The strains were kept at $-80^{\circ} \mathrm{C}$ in $\mathrm{LB}$ broth supplemented with $25 \%$ glycerol. Strains were grown at $25^{\circ} \mathrm{C}$.

\section{Bacteriophage isolation}

Bacteriophages were isolated from samples taken from the intake manifolds, representing an initial stage of the wastewater treatment process, received from the Main Sewage Treatment Plant (GOS) in Lodz or from samples of fish pond water obtained from The Stanisław Sakowicz Inland Fisheries Institute (IRS) in Olsztyn (Table 2.). The enrichment protocol was used following the procedure given by Van Twest and Kropinski [29]. Briefly, wastewater or pond water samples were filtered through a sterile filter with a pore diameter of $0.2 \mu \mathrm{m}$ (Sartorius). Appropriate volume of purified water sample was mixed with the same volume of $2 x$ concentrated LB broth (LabEmpire) and bacterial culture to be used in the enrichment. The enrichment cultures were incubated for $20 \mathrm{~h}$ at $25^{\circ} \mathrm{C}$ with agitation to allow amplification of bacteriophages active against strain used in the enrichment. Following incubation, the culture was centrifuged at $4000 \times \mathrm{g}$, at $4{ }^{\circ} \mathrm{C}$ for $30 \mathrm{~min}$ and supernatant was filtered through a sterile filter $(0.2 \mu \mathrm{m})$. The presence of lytic bacteriophages in supernatant was detected by a modified version of the double-layer method [30]. One 
Table 1 Bacterial strains

\begin{tabular}{|c|c|c|}
\hline Code & Strain & Source \\
\hline R2 & Aeromonas hydrophila 7966 & Current study \\
\hline R3 & Aeromonas hydrophila $1,206,101$ & \\
\hline R5 & Aeromonas sobria & \\
\hline R6 & Aeromonas hydrophila 49,140 & \\
\hline R9 & Aeromonas hydrophila 35,654 & \\
\hline R10 & Aeromonas hydrophila 7965 & \\
\hline R11 & Aeromonas hydrophila 5,247,167 & \\
\hline R12 & $\begin{array}{l}\text { Aeromonas hydrophila } 7965 \\
\text { (290158) }\end{array}$ & \\
\hline R13 & Aeromonas hydrophila 49,140 & \\
\hline R14 & $\begin{array}{l}\text { Aeromonas salmonicida } 33,658 \\
\text { (788242) }\end{array}$ & \\
\hline R15 & Aeromonas hydrophila 33,658 & \\
\hline R16 & Aeromonas hydrophila 35,654 & \\
\hline R40 & $\begin{array}{l}\text { 1B/IRS/03/13_Aeromonas } \\
\text { hydrophila }\end{array}$ & \\
\hline R41 & $\begin{array}{l}\text { 2B/IRS/03/13_Aeromonas } \\
\text { hydrophila }\end{array}$ & \\
\hline R42 & $\begin{array}{l}\text { 3B/IRS/03/13_Aeromonas } \\
\text { hydrophila }\end{array}$ & \\
\hline R43 & $\begin{array}{l}\text { 4B/IRS/03/13_Aeromonas } \\
\text { hydrophila }\end{array}$ & \\
\hline R44 & $\begin{array}{l}\text { 5B/IRS/04/13_Aeromonas } \\
\text { hydrophila }\end{array}$ & \\
\hline R45 & $\begin{array}{l}\text { 6B/IRS/05/13_Aeromonas } \\
\text { hydrophila }\end{array}$ & \\
\hline R46 & $\begin{array}{l}\text { 7B/IRS/05/13_Aeromonas } \\
\text { hydrophila }\end{array}$ & \\
\hline R48 & $\begin{array}{l}\text { 9B/IRS/05/13_Aeromonas } \\
\text { hydrophila }\end{array}$ & \\
\hline R50 & $\begin{array}{l}\text { 11B/IRS/05/13_Aeromonas } \\
\text { hydrophila }\end{array}$ & \\
\hline R52 & $\begin{array}{l}\text { 13B/IRS/06/13_Aeromonas } \\
\text { hydrophila }\end{array}$ & \\
\hline R53 & $\begin{array}{l}\text { 1B/IRS/04/14K_Aeromonas } \\
\text { hydrophila }\end{array}$ & \\
\hline R54 & $\begin{array}{l}\text { 2B/IRS/04/14K_Aeromonas } \\
\text { hydrophila }\end{array}$ & \\
\hline R55 & $\begin{array}{l}\text { 3B/IRS/04/14K_Aeromonas } \\
\text { hydrophila }\end{array}$ & \\
\hline R56 & $\begin{array}{l}\text { 4B/IRS/04/14P_Aeromonas } \\
\text { hydrophila }\end{array}$ & \\
\hline R58 & $\begin{array}{l}\text { 2B/UWM/03/13_Pseudomonas } \\
\text { fluorescens }\end{array}$ & \\
\hline R59 & $\begin{array}{l}\text { 3B/UWM/03/13_Aeromonas } \\
\text { hydrophila }\end{array}$ & \\
\hline R60 & $\begin{array}{l}\text { 4B/UWM/03/13_Pseudomonas } \\
\text { fluorescens }\end{array}$ & \\
\hline R61 & $\begin{array}{l}\text { 5B/UWM/03/13_Pseudomonas } \\
\text { fluorescens }\end{array}$ & \\
\hline R62 & $\begin{array}{l}\text { 6B/UWM/03/13_Pseudomonas } \\
\text { fluorescens }\end{array}$ & \\
\hline
\end{tabular}

Table 1 Bacterial strains (Continued)

\begin{tabular}{|c|c|c|}
\hline Code & Strain & Source \\
\hline R63 & $\begin{array}{l}\text { 7B/UWM/03/13_Pseudomonas } \\
\text { fluorescens }\end{array}$ & \\
\hline R64 & $\begin{array}{l}\text { 8B/UWM/03/13_Pseudomonas } \\
\text { fluorescens }\end{array}$ & \\
\hline R65 & $\begin{array}{l}\text { 9B/UWM/03/13_Aeromonas } \\
\text { hydrophila }\end{array}$ & \\
\hline R67 & $\begin{array}{l}\text { 11B/UWM/03/13_Aeromonas } \\
\text { hydrophila }\end{array}$ & \\
\hline R68 & $\begin{array}{l}\text { 13B/UWM/03/13_Pseudomonas } \\
\text { fluorescens }\end{array}$ & \\
\hline R71 & $\begin{array}{l}\text { 16B/UWM/04/13_Aeromonas } \\
\text { hydrophila/caviae }\end{array}$ & \\
\hline R75 & $\begin{array}{l}\text { 20B/UWM/06/13_Aeromonas } \\
\text { hydrophila }\end{array}$ & \\
\hline R77 & $\begin{array}{l}\text { 22B/UWM/06/13_Aeromonas } \\
\text { sobria }\end{array}$ & \\
\hline R78 & $\begin{array}{l}\text { 23B/UWM/06/13_Aeromonas } \\
\text { hydrophila }\end{array}$ & \\
\hline R80 & $\begin{array}{l}\text { 25B/UWM/07/13_Aeromonas } \\
\text { sobria }\end{array}$ & \\
\hline R82 & $\begin{array}{l}\text { 27B/UWM/07/13_Aeromonas } \\
\text { hydrophila }\end{array}$ & \\
\hline R83 & $\begin{array}{l}\text { 28B/UWM/07/13_Aeromonas } \\
\text { sobria }\end{array}$ & \\
\hline R84 & $\begin{array}{l}\text { 29B/UWM/07/13_Pseudomonas } \\
\text { fluorescens }\end{array}$ & \\
\hline R91 & $\begin{array}{l}\text { 33B/UWM/08/14_Pseudomonas } \\
\text { fluorescens }\end{array}$ & \\
\hline R21 & Aeromonas hydrophila RK 70363 & \multirow{13}{*}{$\begin{array}{l}\text { Adam Mickiewicz University } \\
\text { in Poznań }\end{array}$} \\
\hline R22 & Aeromonas hydrophila SK 3 & \\
\hline R23 & Aeromonas hydrophila ATCC 49140 & \\
\hline R24 & Aeromonas hydrophila LMG 13656 & \\
\hline R25 & Aeromonas hydrophila AK 44 & \\
\hline R26 & Aeromonas hydrophila ATCC $7966^{\top}$ & \\
\hline R28 & Aeromonas sobria CIP $7433^{\top}$ & \\
\hline R29 & $\begin{array}{l}\text { Aeromonas salmonicida LMG } \\
14900^{\top}\end{array}$ & \\
\hline R30 & Aeromonas salmonicida LMG $3782^{\top}$ & \\
\hline R31 & $\begin{array}{l}\text { Aeromonas salmonicida CDC } \\
\text { 0434-84 }\end{array}$ & \\
\hline R32 & Aeromonas salmonicida AK 46 & \\
\hline R33 & Aeromonas salmonicida LMG $3780^{\top}$ & \\
\hline R34 & Aeromonas salmonicidaLMG 13,450 & \\
\hline
\end{tabular}

hundred microliters of bacteriophages was mixed with $100 \mu \mathrm{l}$ of host cells and added to four milliliters of $48^{\circ} \mathrm{C}$ top agar (LB with $0.7 \%$ agar). Then, the mixture was poured onto bottom agar plate (LB with $2 \%$ agar) and incubated for $24 \mathrm{~h}$. The presence of bacteriophages in the form of plaques was detected. All enrichments and phage titrations were carried out at $25^{\circ} \mathrm{C}$. 
Table 2 Bacteriophage strains

\begin{tabular}{lll}
\hline Bacteriophage & Source & Host strain \\
\hline 13AhydR10PP & GOS & Aeromonas hydrophila 7965 \\
14AhydR10PP & GOS & \\
85AhydR10PP & IRS & \\
25AhydR2PP & GOS & Aeromonas hydrophila 7966 \\
50AhydR13PP & GOS & Aeromonas hydrophila 49,140 \\
60AhydR15PP & GOS & Aeromonas hydrophila 33,658 \\
62AhydR11PP & GOS & Aeromonas hydrophila 5,247,167 \\
22PfluR64PP & GOS & Pseudomonas fluorescens 8B/UWM/03/13 \\
67PfluR64PP & GOS & \\
71PfluR64PP & GOS & \\
98PfluR60PP & GOS & Pseudomonas fluorescens 4B/UWM/03/13 \\
\hline
\end{tabular}

For purification of single bacteriophages, a single plaque was picked with a sterile Pasteur pipette and the phages were eluted with shaking for a minimum of $1.5 \mathrm{~h}$ in SM buffer (50 mM Tris-Cl, pH 7.5, $99 \mathrm{mM} \mathrm{NaCl}, 8$ $\mathrm{mM} \mathrm{MgSO} 4,0.01 \%$ gelatin). After chloroform $(50 \mu \mathrm{l} / \mathrm{ml})$ extraction and centrifugation (9000 x g, $5 \mathrm{~min}$, room temp.), the supernatant was transferred to a new tube. Five successive plaque purifications were carried out on each phage isolate.

Phages were annotated by giving a number and abbreviation coming from the host strain name. The phage samples were stored at $4{ }^{\circ} \mathrm{C}$.

\section{Host range}

The host range was determined via spot test against 49 Aeromonas spp. and 9 Pseudomonas sp. strains. Bacterial lawns of each strain were made in triplicates using the double agar overlay method, on which $20 \mu \mathrm{l}$ droplets of the phage stocks (diluted to $10^{6}$ plaque-forming units $(\mathrm{PFU}) / \mathrm{ml})$ were applied. After overnight incubation, the degree of lysis of the lawns was determined. The spot test was repeated three times for each phage. The following spot evaluation system was used: completely clear spot - complete bacterial lysis in the spot, turbid spot-weak bacterial lysis in the spot, no clearing - no bacterial lysis in the spot.

\section{Transmission electron microscopy}

Visualization of bacteriophages by transmission electron microscopy were based on the method described by Maszewska et al. [31]. The high titer bacteriophage lysates were centrifuged at $24500 \mathrm{~g}$ for $3 \mathrm{~h}$ at $4{ }^{\circ} \mathrm{C}$. Then the phages were washed twice with $5 \%$ ammonium molybdate solution (Sigma-Aldrich) pH 6.0 using the above spin conditions. The final sediments were suspended in $5 \%$ ammonium molybdate to obtain the titer of $10^{11} \mathrm{pfu}$ $\mathrm{ml}^{-1}$. Subsequently, one drop of the phage suspension was placed onto the formvar and carbon coated 200-mesh copper grid (Polysciences, Inc., Warrington, USA) and drained for $3 \mathrm{~min}$. Then samples were negatively stained for $45 \mathrm{~s}$. with $2 \%(w / v)$ phosphotungstic acid (PTA) in darkness. The ultrastructure of bacteriophages was visualized by transmission electron microscopy (TEM) with the JEM 1010 electron microscope (JOEL Ltd., Tokyo, Japan) at $80 \mathrm{kV}$ in the Laboratory of Microscopic Imaging and Specialized Biological Techniques of the Faculty of Biology and Environmental Protection, University of Lodz. To examine bacteriophages samples the magnification of 60,000 to 100,000 was used.

\section{DNA extraction and purification}

Genomic DNA were extracted using the modified method of $\mathrm{Su}$ et al. [32]. Briefly, bacteriophage lysates obtained after propagation on host strain was subjected to DNase I for disrupting debris of bacterial DNA. Then, for pelleting the phage particles $2 \mathrm{M} \mathrm{ZnCl}_{2}$ solution in 1:50 (v:v) was used. Next, the phage pellet was dissolved in TENS buffer $(50 \mathrm{mM}$ Tris- $\mathrm{HCl}, \mathrm{pH} 8.0,100 \mathrm{mM}$ EDTA, $100 \mathrm{mM} \mathrm{NaCl}, 0.3 \%$ SDS) supplemented with proteinase K, which disrupted phage capsids. Deproteinated phage DNA was subjected to the extraction by the solution of phenol/chloroform/isoamyl alcohol (25:24:1).

Eluted DNA concentrations were measured using a BioSpectrometer $^{\oplus}$ (Eppendorf, Hamburg, Germany) and stored at $-20^{\circ} \mathrm{C}$ for further analysis.

\section{RFLP analysis}

Digestion reaction was performed by incubating $1 \mu \mathrm{g}$ of isolated DNA with $2.5 \mathrm{U}$ of enzyme (ThermoScientific) in a final reaction volume of $20 \mu \mathrm{l}$ at $37^{\circ} \mathrm{C}$ for $2 \mathrm{~h}$. The restriction fragments were separated by $1.5 \%$ agarose gel electrophoresis in TAE buffer for $2 \mathrm{~h}$ at $30 \mathrm{~V}$ and stained by the nucleic acid stain (SimplySafe ${ }^{\mathrm{Tm}}$, Eurx).

\section{DNA sequencing}

Bacteriophage genomes were sequenced by whole genome sequencing (WGS). Whole-genome shotgun sequencing was performed on the Illumina platform. DNA was sequenced using MiSeq with $2 \times 300$ bp reads and assumed coverage 1000 times. The actual coverage and average contig length for each bacteriophage is presented in (Additional file 1: Table S1.). The draft genomes were de novo assembled by CLC Genomic Workbench 7.5 in Genomed, Poland.

\section{Bioinformatic analysis}

Bioinformatic analysis started with annotation of assembled genomes which was carried out automatically using DNA Master v 5.23.2 based on GeneMarks and Glimmer algorithms (tool written by Dr. Jeffrey Lawrence, the University of Pittsburgh). Then, reference sequences 
were found using the Basic Local Alignment Search Tool (BLASTn), NCBI which allowed to classify analyzed bacteriophages into taxonomic groups. Circular genomic maps were obtained in GenomeVx, a tool for circular chromosome visualisation (http://wolfe.ucd.ie/Geno$\mathrm{meVx} /$, accessed September 2018) while linear maps were prepared in Biopython 1.72. Determination of lytic or lysogenic lifecycle was performed on the basis of PHACTS [33] as well as on careful analysis of each ORF (open reading frame) determined by DNA Master. It was performed both in BLASTp and in HHPred at web service MPI Bioinformatics Toolkit (toolkit.tuebingen.mpg.de/\#/tools/hhpred; accessed February 2018) which finds remote homologs of query amino acid sequences. tRNA genes were searched using ARAGORN, a program to detect tRNA and tmRNA genes [34]. A phylogenetic tree was created based on the sequences of terminase large subunit. The evolutionary history was inferred by using the Maximum Likelihood method and JTT matrix-based model [35]. The tree with the highest log likelihood $(-11,846.74)$ is shown. The percentage of trees in which the associated taxa clustered together is shown next to the branches. Initial tree(s) for the heuristic search were obtained automatically by applying Neighbor-Join and BioNJ algorithms to a matrix of pairwise distances estimated using a JTT model, and then selecting the topology with superior log likelihood value. The tree is drawn to scale, with branch lengths measured in the number of substitutions per site. This analysis involved 17 amino acid sequences. There were a total of 870 positions in the final dataset. Evolutionary analyses were conducted in MEGA X [36]. Identification of antibiotic resistance genes and virulence factors was performed with help of online tools from CGE server: ResFinder 3.0 [37] and VirulenceFinder 1.5 [38]. The genome sequences of phages described in this study were deposited in GenBank under accession numbers: MH179470 - MH179480.

\section{Results}

Thirty six Aeromonas spp. and nine Pseudomonas sp. bacterial strains were isolated from infected fish (Table 1.) and eleven bacteriophage strains were isolated from environment: seven active against Aeromonas spp. and four against Pseudomonas sp., for which 5 Aeromonas hydrophila and 2 Pseudomonas fluorescens strains were used routinely as the hosts (Table 2.).

For all of the phages we assessed the host range: in the case of the Aeromonas phages with a panel of 49 Aeromonas spp. isolates (A. hydrophila, A. salmonicida, A. sobria) and in the case of Pseudomonas phages with $9 P$. fluorescens isolates (Table 3.). The resulting host range patterns were different for each tested phage. The broadest host range had 13AhydR10PP, 14AhydR10PP,
Table 3 Bacteriophages' specificity

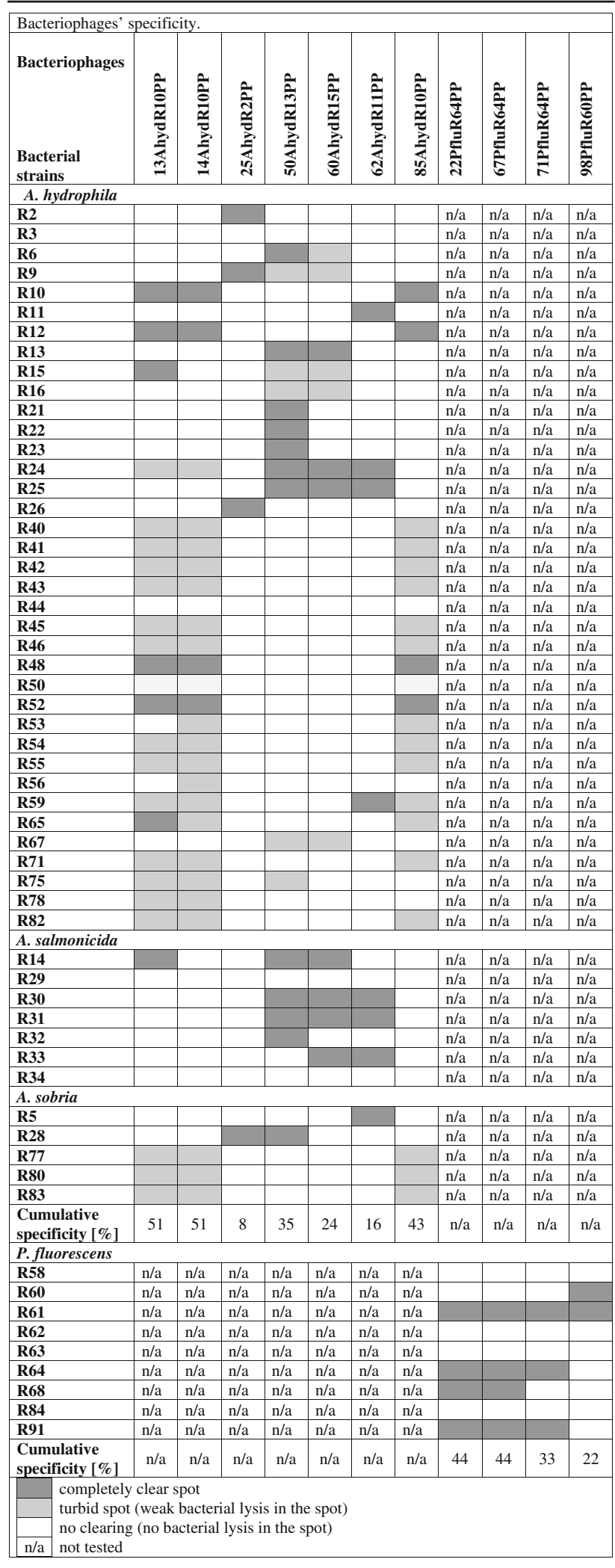



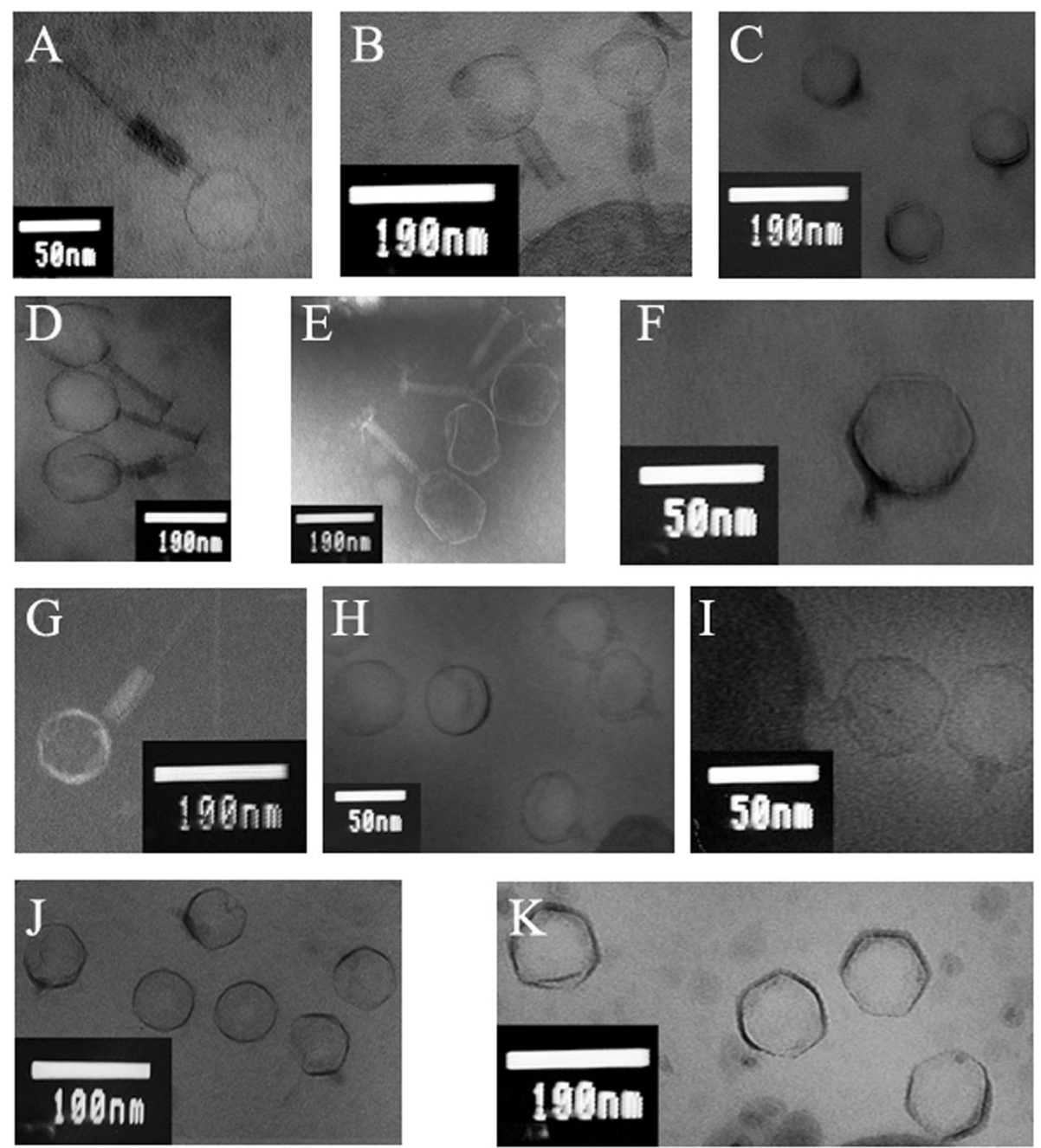

Fig. 1 TEM micrographs of Aeromonas phages: 13AhydR10PP (a, magnification 100,000x), 14AhydR10PP (b, magnification 60,000x), 25AhydR2PP (c, magnification 60,000x), 50AhydR13PP (d, magnification 60,000x), 60AhydR15PP (e, magnification 60,000x), 62AhydR11PP (f, magnification 100,000x), 85AhydR10PP (g, magnification 60,000x), and Pseudomonas phages: 22PfluR64PP (h, magnification 100,000x), 67PfluR64PP (i, magnification 100,000x), 71PfluR64PP (j, magnification 60,000x), 98PfluR60PP (k, magnification 60,000x)

85AhydR10PP, 22PfluR64PP and 67PfluR64PP (42-51\% of bacterial isolates were sensitive to these phages). Phage 25AhydR2PP had the narrowest host range with only $4 / 49(8 \%)$ of bacterial isolates being sensitive to it. Overall, these phages showed different but complementary host ranges.

Visualization of bacteriophages by transmission electron microscopy showed that the tested bacteriophages 13AhydR10PP, 14AhydR10PP, 50AhydR13PP, 60AhydR15PP, 85AhydR10PP consisted of a polyhedral head and tail, which allowed classifying them in the order Caudovirales. In addition those phages were found to have a contracted tail characteristic for viruses belonging to the family Myoviridae. In contrary, phages 22PfluR64PP, 25AhydR2PP, 62AhydR11PP, 67PfluR64PP, 71PfluR64PP, 98PfluR60PP consisted of a polyhedral head and very short tail characteristic for viruses belonging to the family Podoviridae (Fig. 1).

Afterwards, isolation of DNA and restrictive analysis with enzymes: $S s p$ I and EcoRI were carried out. Obtained restriction profiles (Additional file 2: Figure S1.) allowed for the definition of initial genetic characteristics of the bacteriophages. Subsequently, after NGS sequencing (Additional file 1: Table S1.), a detailed genetic analysis of bacteriophages was performed (Table 4.). It was found that phages 13AhydR10PP, 14AhydR10PP and 85AhydR10PP possess genome sizes about $47-48 \mathrm{kbp}$ and belong to double-stranded DNA viruses of Myoviridae family with circular genomes. They are homologues of bacterial viruses: Aeromonas phage 32, Aeromonas phage Asp37, Aeromonas phage 3, Aeromonas phage Ahp2 and Aeromonas phage 59.1. Moreover, their 


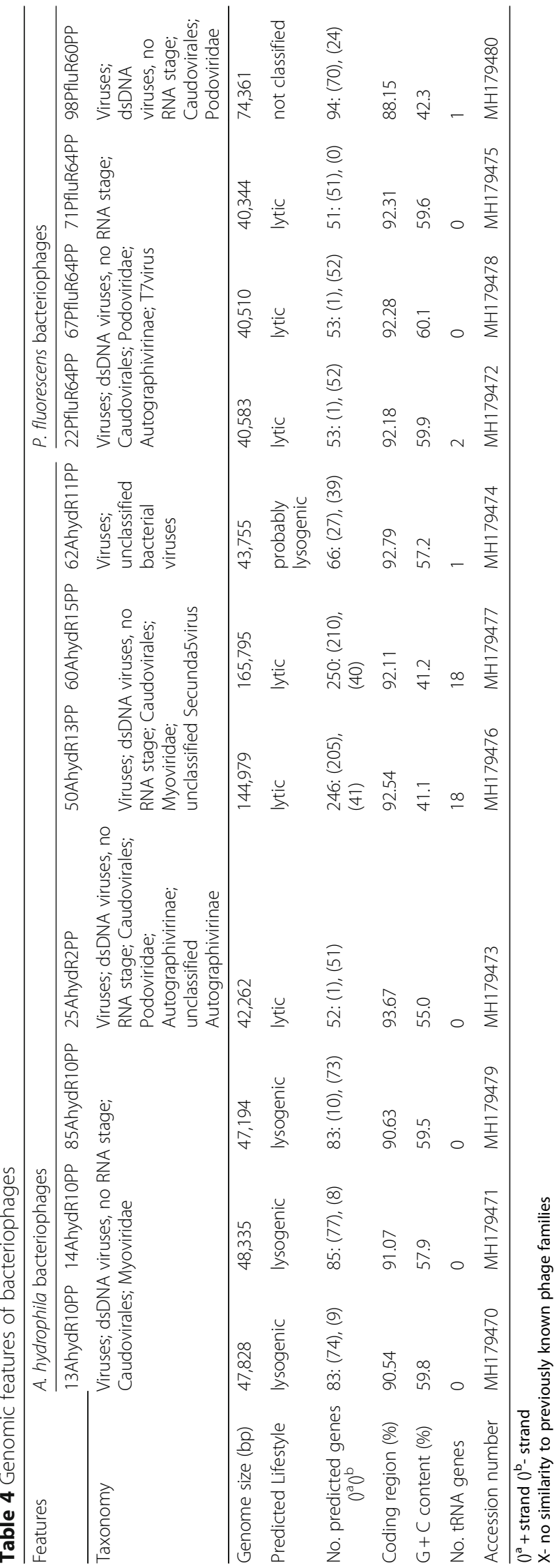




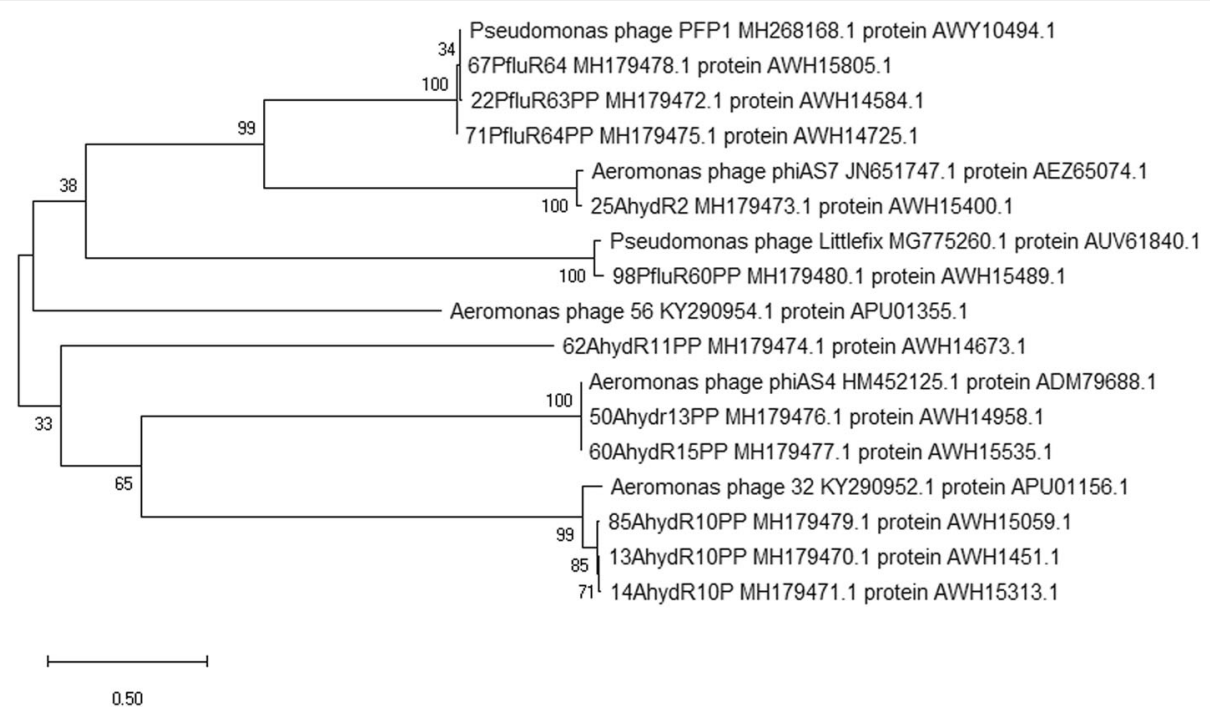

34 67PfluR64 MH179478.1 protein AWH15805.1

Aeromonas phage phiAS7 JN651747.1 protein AEZ65074.1

phage 56 KY290954.1 protein APU01355.1

Aeromonas phage phiAS4 HM452125.1 protein ADM79688.1

60AhydR15PP MH179477. 1 protein AWH15535.1

- Aeromonas phage $32 \mathrm{KY} 290952.1$ protein APU01156.1

13AhydR10PP MH179470.1 protein AWH1451.1

Fig. 2 Phylogenetic tree of phage genomes (phages described in this study together with the reference strains)

lifestyles were classified as lysogenic after conducting bioinformatic analysis, i.e. analysis of presence of genes coding for certain characteristic proteins (such as integrases or resolvases) among their ORFs and analysis of their amino acid sequences in PHACTS. They are highly similar to each other, with $96 \%$ query cover and $96 \%$ identity between 13AhydR10PP and 14AhydR10PP and $78 \%$ query cover and $89 \%$ identity between 13AhydR10PP or 14AhydR10PP and 85AhydR10PP. Phages 50AhydR13PP and 60AhydR15PP were also classified to Myoviridae family (Caudovirales order), containing linear double-stranded DNA (with circularly permuted genome) in size of approximately $165 \mathrm{kbp}$, but showing high similarity to the lytic Myoviridae bacteriophages specific against many bacteria from Aeromonas sp. They are highly similar to each other, with $94 \%$ query cover and 97\% identity. PHACTS classified both of them as confidently lytic. Unclassified phage 62AhydR11PP with genome size of about $44 \mathrm{kbp}$ showed low similarity with Aeromonas-infecting phages of Myoviridae family. It is also similar to the group of viruses with PLPE-like virion morphology. However TEM analysis allowed to classify this phage to Podoviridae family. Careful analysis of its ORFs allowed for the classification of this phage as probably lysogenic. Phages 25AhydR2PP, 22PfluR64PP, 67PfluR64PP and 71PfluR64PP belong to Caudovirales, Podoviridae, Autographivirinae with short, unshrinkable tails and icosaedral capsid containing linear double-stranded DNA of approximately $40 \mathrm{kbp}$ in size. They showed a high similarity to lytic bacteriophages of T7 group specific to bacteria of the Aeromonas and Pseudomonas sp. Genome representations of these phages are linear with direct terminal repeats (DTRs). Among their ORFs no proteins responsible for lysogeny were found. Therefore, it was assumed that they exhibit lytic lifestyle. Phage 98PfluR60PP with genome size about $74 \mathrm{kbp}$ has one reference genome in the NCBI database, i.e. Pseudomonas phage Littlefix active against Pseudomonas sp. It is classified into Podoviridae family, however with ORFs showing no or very little similarity to any known phage proteins therefore it was impossible to classify the genome of 98PfluR60PP as lytic or lysogenic on the basis of current knowledge. Labeled genetic maps (linear or circular depending on the genome) of all analyzed phages are presented in (Additional file 3: Figure S2, Additional file 4: Figure S3, Additional file 5: Figure S4, Additional file 6: Figure S5, Additional file 7: Figure S6, Additional file 8: Figure S7, Additional file 9: Figure S8, Additional file 10: Figure S9, Additional file 11: Figure S10, Additional file 12: Figure S11 and Additional file 13: Figure S12.). Afterwards, all genomes were subjected to phylogenetic analysis (Fig. 2.). The related phages can be divided into the following groups, along with the systematic classification given by GeneBank: Gr.1: 22PfluR63PP, 67PfluR64PP, 71PfluR64PP with the reference strain Pseudomonas phage PFP1, belong to the genus T7virus, Gr.2: 13AhydR10PP, 14AhydR10PP, 85AhydR10PP with the reference strain Aeromonas phage 32 are most likely to belong to the Myoviridae family, Gr.3: 25AhydR2PP together with the reference strain Aeromonas phage phiAS7 belong to the sub-family Autographivirinae, Gr.4: 98PfluR60PP with the reference strain Pseudomonas phage Littlefix belong to the Podoviridae family, Gr.5: 50AhydR13PP, 60AhydR15PP with the reference strain Aeromonas phage phiAS4 belong to the genus unclassified Secunda5virus.

The 62AhydR11PP phage appears to be unique. It has low similarity to phage Aeromonas 56 which is reflected 
Table 5 Taxonomy comparison of Aeromonas and Pseudomonas phage genomes from the database and from this study

\begin{tabular}{|c|c|c|c|c|c|c|c|}
\hline Family & Myoviridae & Podoviridae & Siphoviridae & Inoviridae & Cystoviridae & Leviviridae & unclassified \\
\hline \multicolumn{8}{|c|}{ Aeromonas phages } \\
\hline $\begin{array}{l}\text { Reference } \\
\text { phages }\end{array}$ & $\begin{array}{l}\text { pAh6-C, PX29, Aes012, } \\
\text { CC2, Aes508, vB_AsaM- } \\
\text { 56, phiO18P, 25, 65, } \\
\text { phiAS5, phiAS4, 32, } \\
\text { Asp37, 3, Ahp2, 59.1 }\end{array}$ & phiAS7, Ahp1 & pIS4-A & $x$ & $x$ & $x$ & $x$ \\
\hline $\begin{array}{l}\% \text { of } \\
\text { population }\end{array}$ & 84 & 10 & 6 & $x$ & $x$ & $x$ & $x$ \\
\hline $\begin{array}{l}\text { Phages } \\
\text { from this } \\
\text { study }\end{array}$ & $\begin{array}{l}\text { 13AhydR10PP, } \\
\text { 14AhydR10PP, } \\
\text { 85AhydR10PP, } \\
\text { 50AhydR11PP, } \\
\text { 60AhydR13PP }\end{array}$ & 25AhydR2PP & $x$ & $x$ & $x$ & $x$ & 62AhydR11PP \\
\hline $\begin{array}{l}\% \text { of } \\
\text { population }\end{array}$ & 71 & 14 & $x$ & $x$ & $x$ & $x$ & 14 \\
\hline \multicolumn{8}{|c|}{ Pseudomonas phages } \\
\hline $\begin{array}{l}\text { Reference } \\
\text { phages }\end{array}$ & $\begin{array}{l}\text { vB_PaeM_C2-10_Ab1, } \\
\text { K5, phi3, vB_PsyM_KIL1, } \\
\text { phiMK, K8, DL68, } \\
\text { PhiPA3, vB_Pae_PS44, } \\
\text { PS24, DL60, C11, } \\
\text { vB_PaeM_PAO1_Ab03, } \\
\text { VB_PaeM_C1-14_Ab28, } \\
\text { VB_PaeM_PAO1_Ab27, } \\
\text { SPM-1, phiPsa 374, } \\
\text { PPpW-3, PAK_P5, } \\
\text { PAK_P3, CHA_P1, } \\
\text { PAK_P4, PAK_P2, PaBG, } \\
\text { KPP12, PaP1, JG004, } \\
\text { JG024, NH-4, Lu11, OBP, } \\
\text { PB1, SN, 14-1, LMA2, } \\
\text { LBL3, 201 Phi2-1, F8, EL, } \\
\text { PAK_P1, KPP10 }\end{array}$ & $\begin{array}{l}\text { YMC11/06/ } \\
\text { C171_PPU_BP, PEV2, } \\
\text { Andromeda, } \\
\text { VB_PaeP_MAG4, YH30, } \\
\text { PhiCHU, DL54, DL62, } \\
\text { DL64, KPP21, PPPL-1, } \\
\text { VB_PaeP_PPA-ABTNL, } \\
\text { YH6, Pa2, vB_PaeP_- } \\
\text { PAO1_Ab05, } \\
\text { VB_PaeP_C2-10_Ab22, } \\
\text { phiPSA2, vB_PaeP_C2- } \\
\text { 10_Ab09, KPP25, TL, } \\
\text { PPpW-4, philBB-PAA2, } \\
\text { MPK6, MPK7, Phi-S1, AF, } \\
\text { UFV-P2, tf, vB_Pae-Tbili- } \\
\text { siM32, vB_PaeP_p2- } \\
\text { 10_Or1, Bf7, phikF77, } \\
\text { PT2, PT5, LUZ19, LUZ24, } \\
\text { LKD16, 119X, phiKMV, } \\
\text { PaP2, philBB-PF7A, } \\
\text { phi15, LUZ7, LIT1, phi-2, } \\
\text { Littlefix }\end{array}$ & $\begin{array}{l}\text { KPP23, JBD44, YMC11/ } \\
\text { 07/P54_PAE_BP, phi2, } \\
\text { JBD93, JBD69, MD8, } \\
\text { NP1, PS-1, PaMx11, } \\
\text { PaMx28, PaMx42, } \\
\text { PaMx74, PAE1, } \\
\text { VB_PaeS_PM105, } \\
\text { YMC11/02/R656, H70, } \\
\text { LPB1, vB_Pae- } \\
\text { S_PAO1_Ab18, vB_Pae- } \\
\text { S_PAO1_Ab30, MP48, } \\
\text { VB_PaeS_SCH_Ab26, } \\
\text { phiPSA1, JD024, } \\
\text { PA1KOR, JBD88a, JBD5, } \\
\text { JBD30, JBD24, MP1412, } \\
\text { MP42, vB_Pae-Kakheti25, } \\
\text { PMG1, phi297, MP29, } \\
\text { MP38, PAJU2, Yua, } \\
\text { MP22, DMS3, M6, 73, } \\
\text { F10, B3 }\end{array}$ & Pf1, Pf3 & $\begin{array}{l}\text { phi2954, } \\
\text { phi12, } \\
\text { phi13, phi8 }\end{array}$ & PRR1, PP7 & $\begin{array}{l}\text { 04, vB_PaeM_MAG1, } \\
\text { phiPto-bp6 g, } \\
\text { vB_PaeP_Tr60_Ab31, } \\
\text { PA11 }\end{array}$ \\
\hline $\begin{array}{l}\% \text { of } \\
\text { population }\end{array}$ & 28 & 32 & 31 & 1 & 3 & 1 & 3 \\
\hline $\begin{array}{l}\text { Phages } \\
\text { from this } \\
\text { study }\end{array}$ & $x$ & $\begin{array}{l}\text { 22PfluR64PP, } \\
\text { 67PfluR64PP, } \\
\text { 71PfluR64PP, } \\
\text { 98PfluR60PP }\end{array}$ & $x$ & $x$ & $x$ & $x$ & $x$ \\
\hline $\begin{array}{l}\% \text { of } \\
\text { population }\end{array}$ & $x$ & 100 & $x$ & $x$ & $x$ & $x$ & $x$ \\
\hline
\end{tabular}

on the phylogenetic tree, and they do not occur in the same clade. 62AhydR11PP bacteriophage due to the lack of similar sequences in the NCBI database and separation on the phylogenetic tree may belong to the group of phages that has not been recognized yet. Finally, all of the studied phages are deprived of any antibiotic resistance or virulence genes according to conducted bioinformatics analysis.

\section{Discussion}

Among the entire population of phages only a few have the potential for use in phage therapy. It was previously estimated that only $50 \%$ of phages isolated from the environment are useful for therapeutic purposes [39]. However, the development of new analytical methods, including WGS, can change this proportion. Whole genome sequencing is an indispensable tool used in the study of phage biology [40-43]. WGS facilitates a detailed characterisation of phages that allows them to be classified as useful for therapeutic purposes. Phages that are promising for phage therapy should be excluded of toxin genes, virulence factor genes, and genes responsible for lysogeny [44-47]. In this study, we demonstrated 11 new bacteriophages among which 6 
(25AhydR2PP, 50AhydR13PP, 60AhydR15PP, 22PfluR64PP, 67PfluR64PP, 71PfluR64PP) have a potential to be used in phage therapy due to confirmed lytic lifestyle and absence of virulence or resistance genes. At the same time, we observed (Table 3.) that most of the bacteriophages identified exhibited relatively narrow specificity to bacterial isolates. Selected Aeromonas phages revealed activity against only $8-35 \%$ of the whole examined Aeromonas collection but at the same time shows specificity towards A. hydrophila, A. salmonicida and $A$. sobria. This characteristic is contrary to previously described broad host range Aeromonas phages that act against only one Aeromonas species [13]. Narrow specificity of selected phages might create an obstacle in the development of effective phage treatment for Aeromonas sp. and Pseudomonas sp. infections. One potential way to overcome this challenge would be the creation of a multicomponent phage cocktail, consisting of completely characterized lytic bacteriophages. Using a mixture of bacteriophages to expand the coverage of treatment for heterogenous bacterial populations in bacteriophage therapy has shown high efficacy for many years. However, in most, if not all cases such bacteriophage mixtures do not consist of fully characterized bacteriophages $[48,49]$. Selecting multiple components, that fulfil certain criteria, such as full genomic information, a lack of genes that create safety concerns, negligable risk of lysogenic lifestyle, and reproducible stability in the production environment, creates a significant challenge.

Bacteriophages isolated in this study have also significantly increased the knowledge about Aeromonas and Pseudomonas phages. In currently available genomes in the NCBI database among 19 described Aeromonas phages, 16 belong to Myoviridae (84\% of whole population), only 2 to Podoviridae (10\% of whole population) and 1 to Siphoviridae (6\% of whole population). Myoviridae family members are most likely to be abundant in natural environments $[13,39,50-52]$ and when compared to public databases, it is represented on a similar level in this study (71\%). A comparable situation can be observed for Podoviridae phage population which is represented by $14 \%$ of Aeromonas phages in this study. However among the described collection there was one unclassified phage proving to be unique comparing in the public database. In the case of Pseudomonas phages, 41 genomes from the database belong to Myoviridae (28\% of whole population), 46 belong to Podoviridae (32\% of whole population), 44 belong to Siphoviridae (31\% of whole population), 4 belong to Cystoviridae (3\% of whole population), 2 belong to Leviviridae (1\% of whole population), 2 belong to Inoviridae ( $1 \%$ of whole population) and 5 are unclassified (3\% of whole population). When compared to the publicly available genomes, in the collection described in this study, only the
Podoviridae family is represented and no other phage families were observed in the analyzed set of Pseudomonas phages. The summary of these findings is presented in Table 5.

\section{Conclusions}

To conclude, 11 new bacteriophages were isolated and described on genomic level. Of these, only six have potential for phage therapy in aquaculture due to their proven lytic nature and their lack of antibiotic resistance and virulence genes. Four of them belong to the Podoviridae, while two to the Myoviridae family. The composition of these phages could be used as a therapeutic cocktail giving the cover of $41 \%$ of the Aeromonas and $44 \%$ of Pseudomonas pathogenic environmental isolates. Other phages described in this study should be excluded from any therapeutic cocktail composition due to identification of genes responsible for lysogenesis in their genomes.

\section{Additional files}

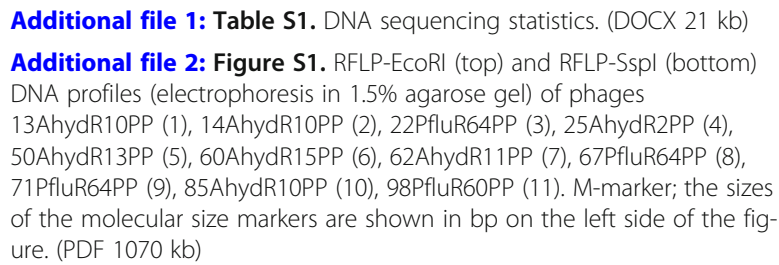

Additional file 3: Figure S2. Genetic map of 13AhydR10PP phage. (PDF $1451 \mathrm{~kb}$ )

Additional file 4: Figure S3. Genetic map of 14AhydR10PP phage. (PDF $1403 \mathrm{~kb}$ )

Additional file 5: Figure S4. Genetic map of 22PfluR64PP phage. (PDF $1374 \mathrm{~kb}$ )

Additional file 6: Figure S5. Genetic map of 25AhydR2PP phage. (PDF $1300 \mathrm{~kb}$ )

Additional file 7: Figure S6. Genetic map of 50AhydR13PP phage. (PDF $3305 \mathrm{~kb}$ )

Additional file 8: Figure S7. Genetic map of 60AhydR15PP phage. (PDF $3192 \mathrm{~kb}$ )

Additional file 9: Figure S8. Genetic map of 62AhydR11PP phage. (PDF $1329 \mathrm{~kb}$ )

Additional file 10: Figure S9. Genetic map of 67PfluR64PP phage. (PDF $1398 \mathrm{~kb}$ )

Additional file 11: Figure S10. Genetic map of 71PfluR64PP phage. (PDF $1445 \mathrm{~kb}$ )

Additional file 12: Figure S11. Genetic map of 85AhydR10PP phage. (PDF $1367 \mathrm{~kb}$ )

Additional file 13: Figure S12. Genetic map of 98PfluR60PP phage. (PDF $1239 \mathrm{~kb}$ )

\section{Abbreviations}

BLASTn: Basic Local Alignment Search Tool; DTR: Direct Terminal Repeat; FDA: Food and Drug Administration; GOS: Main Sewage Treatment Plant in Lodz; IRS: The Stanisław Sakowicz Inland Fisheries Institute in Olsztyn; NCBI: National Center for Biotechnology Information; ORF: Open reading frame; PTA: Phosphotungstic acid; RFLP: Restriction fragment length polymorphism; TEM: Transmission electron microscopy; WGS: Whole genome sequencing 


\section{Acknowledgements}

We would like to thank Prof. Adam Kaznowski group from Adam Mickiewicz University in Poznan (Department of Microbiology) for sharing Aeromoans spp. collection and Dr. Agnieszka Maszewska from University of Lodz (Department of Biology of Bacteria, Faculty of Biology and Environmental Protection) for the support in samples preparation for TEM.

\section{Funding}

Research funded by Project „A new veterinary drug against fish bacterial pathogens" co-financed by the European Regional Development Fund under the Innovative Economy Operational Programme 2007-2013 (POIG.01.04.0010-098 / 12-00)

\section{Availability of data and materials}

The datasets used and/or analysed during the current study are available from the corresponding author on reasonable request.

\section{Authors' contribution}

EK isolated bacterial strains. EAW, EG, JW isolated bacteriophages, performed the experiments and analyzed the data. JW prepared all phage samples for electron microscopy. JK, AG performed bioinformatic analyses. JK, EAW, MS wrote the manuscript. JD, AKS designed the experiment. All authors read and approved the final manuscript.

\section{Ethics approval and consent to participate}

The experiments were carried out in conformity with Animal Protection Law and the recommendations of the Animal Ethics Committee of the University of Warmia and Mazury in Olsztyn.

\section{Consent for publication}

Not applicable.

\section{Competing interests}

The authors declare that they have no competing interests.

\section{Publisher's Note}

Springer Nature remains neutral with regard to jurisdictional claims in published maps and institutional affiliations.

\section{Author details}

'Proteon Pharmaceuticals, Lodz, Poland. ${ }^{2}$ Department of Microbiology and Clinical Immunology, Faculty of Veterinary Medicine, University of Warmia and Mazury in Olsztyn, Olsztyn, Poland.

Received: 25 July 2018 Accepted: 27 December 2018

Published online: 08 January 2019

\section{References}

1. Pereira C, Silva YJ, Santos AL, Cunha A, Gomes NC, Almeida A Bacteriophages with potential for inactivation of fish pathogenic bacteria: survival, host specificity and effect on bacterial community structure. Mar Drugs. 2011;9(11):2236-55. https://doi.org/10.3390/md9112236.

2. Millezi AF, Cardoso M, Alves E, Piccoli RH. Reduction of Aeromonas hidrophyla biofilm on stainless stell surface by essential oils. Braz J Microbiol. 2013;44(1):73-80. https://doi.org/10.1590/S151783822013005000015

3. Sutili FJ, Kreutz LC, Noro M, Gressler LT, Heinzmann BM, de Vargas AC, et al. The use of eugenol against Aeromonas hydrophila and its effect on hematological and immunological parameters in silver catfish (Rhamdia quelen). Vet Immunol Immunopathol. 2014;157(3-4):142-8. https://doi.org/ 10.1016/j.vetimm.2013.11.009.

4. Bandeira Junior G, Sutili FJ, Gressler LT, Ely VL, Silveira BP, Tasca C, et al. Antibacterial potential of phytochemicals alone or in combination with antimicrobials against fish pathogenic bacteria. J Appl Microbiol. 2018. https://doi.org/10.1111/jam.13906.

5. Ghatak S, Blom J, Das S, Sanjukta R, Puro K, Mawlong M, et al. Pan-genome analysis of Aeromonas hydrophila, Aeromonas veronii and Aeromonas caviae indicates phylogenomic diversity and greater pathogenic potential for Aeromonas hydrophila. Antonie Van Leeuwenhoek. 2016:109(7):945-56. https://doi.org/10.1007/s10482-016-0693-6.
6. Paniagua C, Rivero O, Anguita J, Naharro G. Pathogenicity factors and virulence for rainbow trout (Salmo gairdneri) of motile Aeromonas spp. isolated from a river. J Clin Microbiol. 1990;28(2):350-5 https://www.ncbi. nlm.nih.gov/pubmed/2312678.

7. Austin B, Austin DA. Bacterial Fish Pathogens, Disease of farmed and wild fish. 4th ed; 2007.

8. Swain P, Behura A, Dash S, Nayak SK. Serum antibody response of Indian major carp, Labeo rohita to three species of pathogenic bacteria; Aeromonas hydrophila, Edwardsiella tarda and Pseudomonas fluorescens. Vet Immunol Immunopathol. 2007;117(1-2):137-41. https://doi.org/10.1016/ j.vetimm.2007.02.010.

9. Wang HR, Hu YH, Zhang WW, Sun L. Construction of an attenuated Pseudomonas fluorescens strain and evaluation of its potential as a crossprotective vaccine. Vaccine. 2009;27(30):4047-55 https://www.ncbi.nlm.nih. gov/pubmed/19501788.

10. Sun YY, Chi H, Sun L. Pseudomonas fluorescens filamentous hemagglutinin, an iron-regulated protein, is an important virulence factor that modulates bacterial pathogenicity. Front Microbiol. 2016;7:1320. https://doi.org/10. 3389/fmicb.2016.01320.

11. Watts JEM, Schreier HJ, Lanska L, Hale MS. The rising tide of antimicrobial resistance in aquaculture: sources, sinks and solutions. Mar Drugs. 2017; 15(6). https://doi.org/10.3390/md15060158.

12. Matyar F, Akkan T, Uçak Y, Eraslan B. Aeromonas and Pseudomonas: antibiotic and heavy metal resistance species from Iskenderun Bay, Turkey (Northeast Mediterranean Sea). Environ Monit Assess. 2010;167(1-4):309-20. https://doi.org/10.1007/s10661-009-1051-1.

13. Le TS, Nguyen TH, Vo HP, Doan VC, Nguyen HL, Tran MT, et al. Protective effects of bacteriophages against Aeromonas hydrophila species causing motile Aeromonas septicemia (MAS) in striped catfish. Antibiotics. 2018;7(1). https://doi.org/10.3390/antibiotics7010016.

14. Kokkari C, Sarropoulou E, Bastias R, Mandalakis M, Katharios P. Isolation and characterization of a novel bacteriophage infecting Vibrio alginolyticus. Arch Microbiol. 2018;200(5):707-18. https://doi.org/10.1007/s00203-018-1480-8.

15. Richards GP. Bacteriophage remediation of bacterial pathogens in aquaculture: a review of the technology. Bacteriophage. 2014;4(4):975540. https://doi.org/10.4161/21597081.2014.975540.

16. Letchumanan V, Chan KG, Pusparajah P, Saokaew S, Duangjai A, Goh BH, et al. Insights into bacteriophage application in controlling Vibrio species. Front Microbiol. 2016;7:1114. https://doi.org/10.3389/fmicb.2016.01114.

17. Vinod MG, Shivu MM, Umesha KR, Rajeeva BC, Krohne G, Karunasagar I, et al. Isolation of Vibrio harveyi bacteriophage with a potential for biocontrol of luminous vibriosis in hatchery environments. Aquaculture. 2006:255:11724. https://doi.org/10.1016/j.aquaculture.2005.12.003.

18. Karunasagar I, Shivu MM, Girisha SK, Krohne G, Karunasagar I. Biocontrol of pathogens in shrimp hatcheries using bacteriophages. Aquaculture. 2007; 268:288-92. https://doi.org/10.1016/j.aquaculture.2007.04.049.

19. Hiquera G, Bastías R, Tsertsvadze G, Romero J, Espejo RT. Recently discovered Vibrio anguillarum phages can protect against experimentally induced vibriosis in Atlantic salmon, Salmo salar. Aquaculture. 2013;392-395: 128-33. https://doi.org/10.1016/j.aquaculture.2013.02.013.

20. Mateus L, Costa L, Silva YJ, Pereira C, Cunha A, Almeida A. Efficiency of phage cocktails in the inactivation of Vibrio in aquaculture. Aquaculture. 2014:424-425:167-73. https://doi.org/10.1016/j.aquaculture.2014.01.001.

21. Silva YJ, Costa L, Pereira C, Mateus C, Cunha A, Calado R, et al. Phage therapy as an approach to prevent Vibrio anguillarum infections in fish larvae production. PLoS One. 2014;9(12):114197. https://doi.org/10.1371/ journal.pone.0114197.

22. Tan D, Gram L, Middelboe M. Vibriophages and their interactions with the fish pathogen Vibrio anguillarum. Appl Environ Microbiol. 2014;80(10):312840. https://doi.org/10.1128/AEM.03544-13.

23. Khairnar K, Raut MP, Chandekar RH, Sanmukh SG, Paunikar WN. Novel bacteriophage therapy for controlling metallo-beta-lactamase producing Pseudomonas aeruginosa infection in catfish. BMC Vet Res. 2013;9:264. https://doi.org/10.1186/1746-6148-9-264.

24. Rørbo N, Rønneseth A, Kalatzis PG, Rasmussen BB, Engell-Sørensen K, Kleppen HP, et al. Exploring the effect of phage therapy in preventing. Antibiotics. 2018;7:2. https://doi.org/10.3390/antibiotics7020042.

25. Hendrix RW. Evolution: the long evolutionary reach of viruses. Curr Biol. 1999;9:914-7. https://doi.org/10.1016/S0960-9822(00)80103-7.

26. Hendrix RW. Bacteriophages: evolution of the majority. Theor Popul Biol. 2002;61:471-80. https://doi.org/10.1006/tpbi.2002.1590. 
27. Borrell N, Acinas SG, Figueras MJ, Martínez-Murcia AJ. Identification of Aeromonas clinical isolates by restriction fragment length polymorphism of PCR-amplified 16S rRNA genes. J Clin Microbiol. 1997;35(7):1671-4 https:// www.ncbi.n/m.nih.gov/pubmed/9196171.

28. Scarpellini M, Franzetti L, Galli A. Development of PCR assay to identify Pseudomonas fluorescens and its biotype. FEMS Microbiol Lett. 2004;15: 257-60. https://doi.org/10.1016/j.femsle.2004.05.043.

29. Van Twest R, Kropinski AM. Bacteriophage enrichment from water and soil. Methods Mol Biol. 2009;501:15-21. https://doi.org/10.1007/978-1-60327-164-6_2.

30. Adams MH. Bacteriophages; 1959

31. Maszewska A, Zygmunt M, Grzejdziak I, Różalski A. Use of polyvalent bacteriophages to combat biofilm of Proteus mirabilis causing catheterassociated urinary tract infections. J Appl Microbiol. 2018;125(5):1253-65. https://doi.org/10.1111/jam.14026 Epub 2018 Jul 18.

32. Su MT, Venkatesh TV, Bodmer R. Large- and small-scale preparation of bacteriophage lambda lysate and DNA. BioTechniques. 1998;25(1):44-6 https://www.ncbi.nlm.nih.gov/pubmed/9668973.

33. McNair K, Bailey BA, Edwards RA. PHACTS, a computational approach to classifying the lifestyle of phages. Bioinformatics. 2012;28(5):614-8. https:// doi.org/10.1093/bioinformatics/bts014.

34. Laslett D, Canback BARAGORN. A program to detect tRNA genes and tmRNA genes in nucleotide sequences. Nucleic Acids Res. 2004;32(1):11-6. https://doi.org/10.1093/nar/gkh152.

35. Jones DT, Taylor WR, Thornton JM. The rapid generation of mutation data matrices from protein sequences. Comput Appl Biosci. 8:275-82. https://doi. org/10.1093/bioinformatics/8.3.275.

36. Kumar S, Stecher G, Li M, Knyaz C, Tamura K. MEGA X: molecular evolutionary genetics analysis across computing platforms. Mol Biol Evol. 35: 1547-9. https://doi.org/10.1093/molbev/msy096.

37. Zankari E, Hasman H, Cosentino S, Vestergaard M, Rasmussen S, Lund O, et al. Identification of acquired antimicrobial resistance genes. J Antimicrob Chemother. 2012;67(11):2640-4. https://doi.org/10.1093/jac/dks261.

38. Joensen KG, Scheutz F, Lund O, Hasman H, Kaas RS, Nielsen EM, et al. Realtime whole-genome sequencing for routine typing, surveillance, and outbreak detection of verotoxigenic Escherichia coli. J Clin Microbiol. 2014; 52(5):1501-10. https://doi.org/10.1128/JCM.03617-13.

39. Ackermann HW. 5500 phages examined in the electron microscope. Arch Virol. 2007;152(2):227-43. https://doi.org/10.1007/s00705-006-0849-1.

40. Clark CG, Chen CY, Berry C, Walker M, McCorrister SJ, Chong PM, et al. Comparison of genomes and proteomes of four whole genome-sequenced campylobacter jejuni from different phylogenetic backgrounds. PLoS One. 2018;13(1):0190836. https://doi.org/10.1371/journal.pone.0190836.

41. Wang JB, Lin NT, Tseng YH, Weng SF. Genomic characterization of the novel Aeromonas hydrophila phage Ahp1 suggests the derivation of a new subgroup from phiKMV-like family. PLoS One. 2016;11(9):0162060. https:// doi.org/10.1371/journal.pone.0162060.

42. Wojtus JK, Fitch JL, Christian E, Dalefield T, Lawes JK, Kumar K, et al. Complete genome sequences of three novel. Genome Announc. 2017;5(31). https://doi.org/10.1128/genomeA.00725-17.

43. Nowicki G, Walkowiak-Nowicka K, Zemleduch-Barylska A, Mleczko A, Frąckowiak P, Nowaczyk N, et al. Complete genome sequences of two novel autographiviruses infecting a bacterium from the Pseudomonas fluorescens group. Arch Virol. 2017;162(9):2907-11. https://doi.org/10.1007/ s00705-017-3419-9.

44. Morrison S, Rainnie DJ. Bacteriophage therapy: an alternative to antibiotic theraphy in aquaculture? Fisheries and oceans. 2004. ISSN: 0706-6457.

45. Skurnik M, Strauch E. Phage therapy: facts and fiction. Int J Med Microbiol. 2006;296(1):5-14. https://doi.org/10.1016/j.ijmm.2005.09.002.

46. Pirnay JP, De Vos D, Verbeken G, Merabishvili M, Chanishvili N, Vaneechoutte $M$, et al. The phage therapy paradigm: prêt-à-porter or Surmesure? Pharm Res. 2011;28(4):934-7. https://doi.org/10.1007/s11095-0100313-5.

47. Weber-Dąbrowska B, Jończyk-Matysiak E, Żaczek M, Łobocka M, ŁusiakSzelachowska M, Górski A. Bacteriophage procurement for therapeutic purposes. Front Microbiol. 2016;7:1177. https://doi.org/10.3389/fmicb.2016. 01177.

48. Zhang J, Kraft BL, Pan Y, Wall SK, Saez AC, Ebner PD. Development of an anti-Salmonella phage cocktail with increased host range. Foodborne Pathog Dis. 2010;7(11):1415-9. https://doi.org/10.1089/fpd.2010.0621.

49. Seo BJ, Song ET, Lee K, Kim JW, Jeong CG, Moon SH, et al. Evaluation of the broad-spectrum lytic capability of bacteriophage cocktails against various
Salmonella serovars and their effects on weaned pigs infected with Salmonella typhimurium. J Vet Med Sci. 2018;80(6):851-60. https://doi.org/ 10.1292/jvms.17-0501.

50. UI Haq I, Chaudhry WN, Andleeb S, Qadri I. Isolation and partial characterization of a virulent bacteriophage $\mathrm{HHQ1}$ specific for Aeromonas punctata from stream water. Microb Ecol. 2012;63(4):954-63. https://doi.org/ 10.1007/s00248-011-9944-2.

51. Jun JW, Kimb JH, Shina SP, Hana JE, Chai JY, Park SC. Protective effects of the Aeromonas phages pAh1-C and pAh6-C against mass mortality of the cyprinid loach (Misgurnus anguillicaudatus) caused by Aeromonas hydrophila. Aquaculture. 2013;416-417:289-95. https://doi.org/10.1016/j. aquaculture.2013.09.045

52. Kim JH, Son JS, Choi YJ, Choresca CH, Shin SP, Han JE, et al. Isolation and characterization of a lytic Myoviridae bacteriophage PAS-1 with broad infectivity in Aeromonas salmonicida. Curr Microbiol. 2012;64(5):418-26. https://doi.org/10.1007/s00284-012-0091-x

\section{Ready to submit your research? Choose BMC and benefit from:}

- fast, convenient online submission

- thorough peer review by experienced researchers in your field

- rapid publication on acceptance

- support for research data, including large and complex data types

- gold Open Access which fosters wider collaboration and increased citations

- maximum visibility for your research: over $100 \mathrm{M}$ website views per year

At $\mathrm{BMC}$, research is always in progress.

Learn more biomedcentral.com/submissions 